\title{
CDISC SDTM Hepatic Findings About Test Name Terminology
}

National Cancer Institute

\section{Source}

National Cancer Institute. CDISC SDTM Hepatic Findings About Test Name Terminology. NCI Thesaurus. Code C117738.

Terminology associated with the hepatic findings about test names codelist of the Clinical Data Interchange Standards Consortium (CDISC) Study Data Tabulation Model (SDTM). 